EREM 72/2

Journal of Environmental Research, Engineering and Management Vol. 72 / No. 2 / 2016 pp. $21-30$

DOI 10.5755/j01.erem.72.2.16213 (c) Kaunas University of Technology
Polychlorinated Biphenyls (PCBs) in Open Systems in Lithuania

Received 2016/06

Accepted after revision 2016/09

\title{
Polychlorinated Biphenyls (PCBs) in Open Systems in Lithuania
}

Jolita Kruopienè, Eglè Jurkènè, Jolanta Dvarionienè

Kaunas University of Technology, Institute of Environmental Engineering

Gedimino 50, LT-44239 Kaunas, Lithuania

\section{Gintaras Buika}

Kaunas University of Technology, Department of Chemical Technology

Radvilènu 19A, Kaunas, Lithuania

\section{Sigita Židonienè}

Baltic Environmental Forum Lithuania

Užupio 9/2- 17, LT-01202 Vilnius, Lithuania

\section{Corresponding author: jolita.kruopiene@ktu.lt}

J. Kruopienè, Kaunas University of Technology, Institute of Environmental Engineering

Gedimino 50, LT-44239 Kaunas, Lithuania

Polychlorinated biphenyls (PCBs) are toxic, persistent and bio-accumulative substances that have been included into the Stockholm Convention due to their hazardous properties. While large efforts have been made in the past decades to phase-out closed systems containing PCBs, open systems have received much less attention. In Lithuania, too, transformers and capacitors (closed systems) have already been inventoried and mostly collected and destroyed, but PCBs in open systems, mainly in buildings, have not been investigated. Therefore, this article presents estimates of probable PCB amounts and distribution in buildings in the country. According to theoretical calculations, about 1,900 t of PCBs could be brought into Lithuania and used in closed, partially closed and open systems. It is most probable that PCBs under the trade name Sovol, produced in Russia, constituted the majority of PCBs in open systems, i.e. some 400 t. There are about 8,600 apartment houses and 51,950 various public buildings with a big probability to contain PCBs. One such building could contain up to $6.6 \mathrm{~kg}$ of PCBs.

Keywords: polychlorinated biphenyls - PCBs, open systems, PCBs in buildings, Stockholm convention. 


\section{Introduction}

Polychlorinated biphenyls (PCBs) are toxic, persistent and bio-accumulative substances that have been included into the Stockholm Convention due to their hazardous properties (UNEP 2001). The Stockholm Convention, which entered into force in 2004 , has an objective to protect human health and the environment from persistent organic pollutants (POPs). It requires Convention parties to prohibit (with just a few exemptions) production and use of intentionally produced POPs, and reduce or eliminate releases from unintentionally produced POPs that are listed in the Convention. It also requires ensuring that stockpiles and wastes consisting of, containing or contaminated with POPs are managed safely and in an environmentally sound manner.

As the characteristics of PCBs are quite advantageous from a technical point of view, they used to be employed in a wide range of applications. Production and use of PCBs peaked around 1970s; the most widespread use was in capacitors and transformers. Over time, evidence about the adverse effects of PCBs on the environment and human health has accumulated, and, thus, PCB-related prohibitions have increasingly come into force (Breivik et al. 2002, Breivik et al. 2007).

The Stockholm Convention states that each Party shall develop a plan, the so-called National Implementation Plan (NIP), for the implementation of its obligations under the Convention. When developing the first NIPs, Convention parties paid their main attention namely to the use of PCBs in capacitors and transformers, i.e. in closed systems
(Wagner 2010). In Lithuania, capacitors and transformers with PCB containing oil have already been inventoried and largely disposed of (Lithuanian MoE 2010).

Scientists in some countries, such as Switzerland, Germany, Denmark, and the US, have pointed out that PCBs had quite widespread use in open systems as well, mostly in buildings: sealants, paints (e.g. concrete), steel anticorrosive coatings, electrical cable protection, etc. Investigations have shown that PCBs can be detected not only in construction materials but also in indoor air (Kohler et al. 2005, Maclntosh et al. 2012, Butera et al. 2014). It has been estimated that approximately $21 \%$ of PCBs were used for open uses (Breivik et al 2007). Therefore, the next step, when updating NIPs, shall be paying sufficient attention to PCBs in open systems.

This article presents estimates of PCBs in buildings in Lithuania and places them into the overall picture of PCB usage. These estimates are needed to update the Lithuanian NIP on POPs under the Stockholm Convention, as well as are helpful in attempts to protect human health and environment from exposure to PCBs.

\section{Materials and methods}

Sequence of research steps is shown in Fig. 1. Estimation of PCBs in open uses (buildings) in Lithuania started from data collection both from literature sources and potential information sources in the country; then, it was followed by screening level laboratory analysis of potentially contaminated samples. Finally, calculations of potential amounts of PCBs in buildings (estimates) were made.

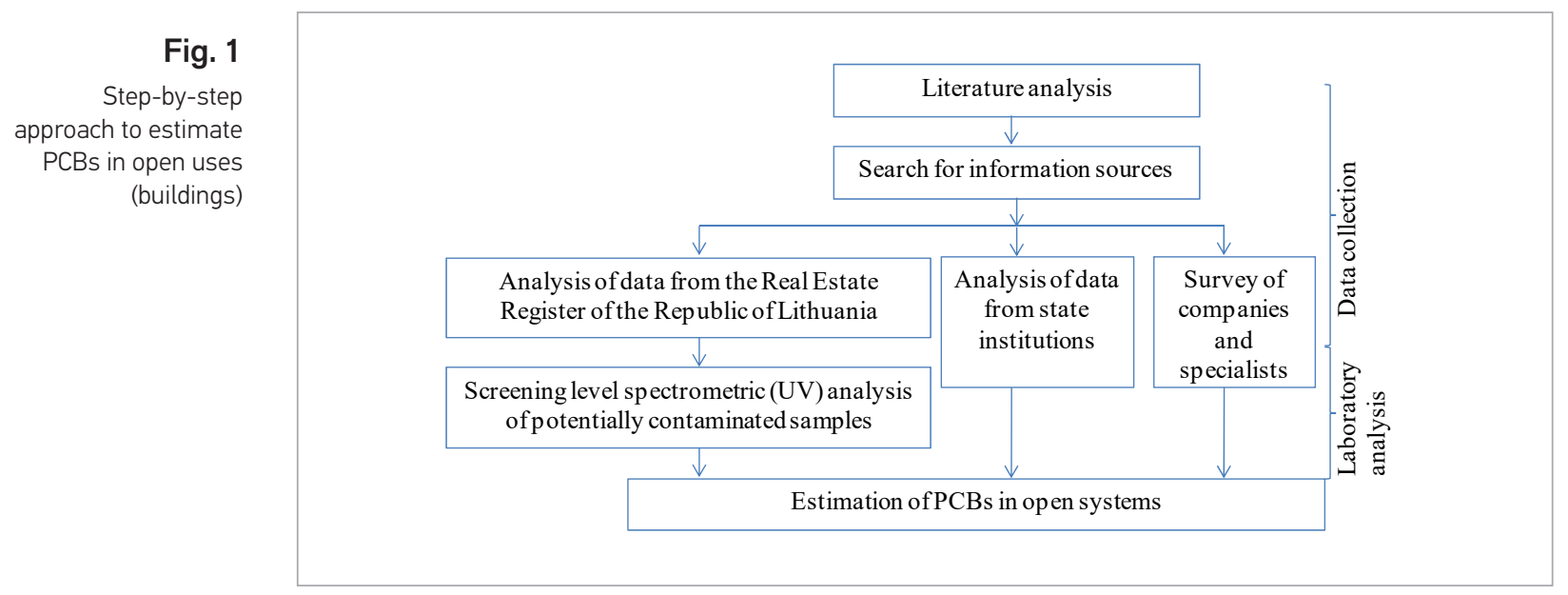




\section{Data collection}

Documents developed by the Stockholm Convention Secretariat and the European Commission (can be accessed via http://chm.pops.int/default.aspx and http:// ec.europa.eu/environment/waste/pcbs/index.htm), NIPs of different countries, research papers, reports, other written sources of information were analysed in order to find out information on production and usage of PCBs and their pathways to the environment.

Available data about the situation in Lithuania were collected from the Lithuanian Ministry of Environment and Environmental Protection Agency, Lithuanian Statistics Department (official statistics database http://osp.stat. gov.lt), and the Lithuanian Real Property Register. Specialists from municipalities and experts of construction materials were contacted as well. And finally, questionnaires were sent and telephone calls were made to the biggest hazardous waste management companies, having licenses to treat PCB containing construction and demolition waste (8 companies), construction demolition companies with long working experience (8 companies), and construction and renovation companies that were active during 1950s-1970s (4 companies).

\section{Laboratory analysis}

PCBs in construction materials of buildings can be quantitatively detected by gas chromatography - mass spectrometry (GS-MS). However, due to the high cost of the method, as long as nothing is known for sure about the spread of PCBs in specific buildings and specific construction materials, screening spectrometric analysis can be an acceptable solution. If necessary, samples which show that they contain chlorinated aromatic compounds can undergo further detailed analysis.

In the current research, namely initial screening by UV and visible light absorption spectrometry method was carried out. Ten samples from residential and public buildings built in the city of Kaunas and in Kaunas district in the period of 1950s-1970s were analysed:
1 residential house, concrete (1958);
2 residential house, paint (1969);
3 residential house, sealant (1960);
4 the old trolley park, concrete (1965);
5 residential house, paint (1970);

6 residential house, concrete (1965);

7 residential house, paint (1961);

8 secondary school, concrete (1952);

9 residential house, paint (1955);

10 residential house, paint (1955).

UV - visual light absorption spectrometer SPECORD UV/VIS was used for analysis. The device was calibrated with hexane solution, $>99.0 \%$ grade (Sigma-Aldrich, USA). The samples $(\sim 1-2 \mathrm{~g})$ were placed into glass bottles and $5 \mathrm{~mL}$ of hexane was added. Then the solutions were filtered after 15-min shaking on a laboratory shaker. The prepared samples went for UV/VIS spectrometric analysis (Buika et al., 2007).

\section{Results and discussion}

\section{Literature analysis for background information}

The cumulative global production of PCBs has been estimated to be on the order of 1.5 million tonnes (Breivik 2002). Production of PCBs and their mixtures started in 1929 in the USA by Monsanto and soon spread into other countries, such as Germany, Czechoslovakia, the Soviet Union, Austria, China, France, Italy, Japan, Spain, Great Britain and other. The United States remained the largest producer until 1977; 600,000 t of PCBs were produced in the USA during that period. Production in Europe was almost 450,000 t; it was most widespread in the period of 1934-1982 (Breivik 2002, Breivik 2007). It has been estimated that globally approximately $69 \%$ were used in closed systems $(\sim 48 \%$ in transformer oil and $\sim 21 \%$ for small capacitors), approximately $10 \%$ in partially closed systems, and approximately $21 \%$ for open uses (Breivik 2007). According to Guidelines for Identification of PCBs and Materials Containing PCBs (UNEP 1999), closed and partially closed systems contain PCB oils and fluids. PCBs in open applications may be found in lubricants, various surface coatings (e.g. paints, flame retardants, carbonless copy paper), adhesives, plasticisers (e.g. sealants, rubber, PVC), inks, etc. While large efforts have been made in the past decades to phase-out closed systems containing PCBs, such as transformers and capacitors, open systems, being 
more complicated to deal with, have received less attention (Kohler et al., 2005).

PCBs were used in various construction materials: as plasticisers in sealants for various seams, in paints, glues, concrete and gypsum, sealants for glass packages, wall tiles, etc. Such construction materials were used to build residential and public buildings, the peak consumption covering approximately 1950s until 1970s (Heinzow et al., 2007). Different countries have different main usage of PCBs in buildings. Although exact usages and numbers are not known, some existing estimates are summarised in Table 1.

Human and environmental exposure from PCBs in open uses, if these are not addressed properly, is an important issue. Indoor air concentrations of PCBs in some buildings are one or more orders of magnitude higher than background levels (Lehman et al., 2015). Unacceptable exposure cases have been reported from various countries (Herrik et al., 2004, Kohler et al., 2005, Heinzow et al., 2007, Maclntosh et al., 2012). PCBs have been detected also in indoor air of new buildings (Kauneliene et al., 2016). Risk exists to those spending their time indoor, but even to construction workers dealing with contaminated materials (Selden et al., 2008). Butera and others (Butera et al., 2014) have addressed the issue of the presence of PCBs in construction and demolition waste, which is going to be utilised. Having in mind exposure to PCBs, increasingly more attention is being paid to appropriate mitigation and abatement methods, as well as to cost-efficiency, as costs of managing PCB-containing construction materials can be substantial (Maclntosh et al., 2012, Brown et al., 2016).

\section{PCBs in open systems in Lithuania}

At the time when PCBs were produced and consumed, Lithuania was part of the Soviet Union, whose economy was relatively closed. OECD (Organisation of Economic Cooperation and Development) countries traded with each other and the likelihood that PCBs came to Lithuania from these countries is very low. In Eastern Europe, PCBs during 1939-1993 were produced in Poland and Czechoslovakia (Breivik et al., 2007). However, Poland produced just over 1,000 t, and it is likely that the entire amount went for internal market. There is a chance that Lithuania could get a small amount of PCBs produced in Czechoslovakia. However, the main amount had to come from production in the Soviet Union. There were two factories - Orgsteklo and Orgsintez - situated

\begin{tabular}{|c|c|c|c|c|c|c|}
\hline \multirow{5}{*}{$\begin{array}{r}\text { Amount of } \\
\text { construction } \\
\text { materials containing } \\
\text { PCBs that were used } \\
\text { during } 1950 \text { s-1970s } \\
\text { (Benthe et al., } \\
\text { 1992, Breivik et al., } \\
\text { 2002, Herrick 2010, } \\
\text { Anderssson et al., } \\
\text { 2004, Priha et al., } \\
\text { 2005, WHO/IPCS } \\
\text { 1993) }\end{array}$} & Country & $\begin{array}{l}\text { Sealants } \\
\text { with } \\
\text { PCBs (t) }\end{array}$ & $\begin{array}{l}\text { Concrete and } \\
\text { gypsum with } \\
\text { PCBs (t) }\end{array}$ & $\begin{array}{l}\text { Paint with } \\
\text { PCBs (t) }\end{array}$ & $\begin{array}{l}\text { Total amount of } \\
\text { construction mate- } \\
\text { rials with PCBs }\end{array}$ & $\begin{array}{l}\text { Amount of construction } \\
\text { materials with PCBs in } \\
\text { one residential house, } \mathrm{kg}\end{array}$ \\
\hline & 1 & 2 & 3 & 4 & 5 & 6 \\
\hline & Germany & 3,500 & & 800 & 24,200 & $40-100$ \\
\hline & Sweden & 250 & & 50 & & \\
\hline & Finland & 250 & & & & \\
\hline & Switzerland & 300 & & 50 & & \\
\hline & Denmark & 320 & 75 & 270 & & \\
\hline & Norway & 50 & 85 & 10 & & \\
\hline & France & & & & 16,200 & \\
\hline & Italy & & & & 4,500 & \\
\hline & Spain & & & & 3,400 & \\
\hline
\end{tabular}


in Russia that produced PCBs under three brand names - Sovol, Sovtol and Trichlorbiphenyl (TCB) (AMAP 2000). In total, $179,500 \mathrm{t}$ of PCBs were produced during 1939-1993. Sovtol was used in transformers, TCB in capacitors, and Sovol mostly as a plasticiser in paints and varnishes, as well as lubricants. The total produced amount of Sovol was 53,000 t, which was consumed for the following purposes (AMAP 2000):

_ 37,000 t consumed in the production of varnish and paint;

_ 10,000 $t$ consumed in the production of lubricants;

_ 5,500 t consumed in defence-related industry plants and other industrial enterprises; use not specified.

According to AMAP 2000, PCB exports from and imports to the Soviet Union were not big and probably flows offset each other. Calculations show that the distribution of the proportions between the usages in closed and open systems in the Soviet Union was the same as in other countries (69\% in closed, 10\% in partially closed, and $21 \%$ in open systems (Breivik et al., 2007)):

\section{9,500 t produced PCBs, total - $\quad$ 100\% \\ 37,000 t Sovol in open systems $\quad-\quad x \% \quad x \approx 21 \%$}

The report also states that $60 \%$ of PCBs intended for transformers and capacitors remained in Russia; the rest went elsewhere (AMAP 2000). It is assumed that the distribution of Sovol between Russia and the other republics of the Soviet Union was similar, i.e. $60 \%$ remained in Russia, and $40 \%$ went outside Russia. As this figure of $60 \%$ of remaining PCBs in Russia is close to the population distribution of the Soviet Union (according to population census of 1989 (http://en.wikipedia.org/wiki/Demographics_of_the_Soviet_Union), $51 \%$ of the population of the Soviet Union lived in Russia), then Lithuania's share of PCBs can be calculated based on the Lithuanian population (1989 population census data):

$$
\begin{array}{lll}
\text { USSR population } & - & 286,717 \mathrm{M} \\
\text { Russian population } & - & 147,386 \mathrm{M} \\
\text { Lithuanian population } & - & 3.69 \mathrm{M} \text {, i.e. } 2.65 \% \\
& & \text { of non-Russian population. }
\end{array}
$$

Import of PCBs to the other (than Russia) Republics of the Soviet Union:

$$
\begin{aligned}
179,500 t & -100 \% \\
x t & -40 \% \quad x \approx 71,800 t P C B .
\end{aligned}
$$

Import of PCBs to Lithuania:

$$
\begin{aligned}
71,800 t & -100 \% \\
x t & -2.65 \%
\end{aligned}
$$

Based on the estimated amount of PCBs imported to Lithuania and on the known percentage distribution, the expected distribution between closed, partially closed and open systems in Lithuania can be calculated:
In closed systems 69\%:
1,310 tPCB;
In partially closed systems 10\%:
190 t $P C B$;
In open systems $21 \%$ :
400 t PCB.

The amount of PCBs in open systems can also be calculated directly from the amount of Sovol, which was consumed for plasticisers $(37,000 \mathrm{t})$, which gives the same amount, $\sim 400 \mathrm{t}$ :

\begin{tabular}{rlll}
\hline $37,000 t$ & - & $100 \%$ & \\
$x t$ & - & $40 \%$ & \\
& & & \\
\hline $14,800 t$ & - & $100 \%$ & \\
$x t$ & - & $2.65 \%$ & $x \approx 392.800$ t PCB.
\end{tabular}

It should be noted that these calculations resulted in higher amount of PCBs in closed systems in the country than it was identified when developing the first Lithuanian NIP, and also during the subsequent inventory in 2009 (Lithuanian MoE 2010).

\section{PCBs in buildings in Lithuania}

Occurrence of PCBs in buildings in Lithuania was assessed on the basis of assumptions made by analogy with other countries, where investigations on PCBs in buildings have been carried out. Information 
on the age of buildings in the country was received from the State Enterprise Centre of Registers, which is responsible for keeping the Real Property Cadastre and Register. It could provide data on the numbers of buildings, registered in the country in the periods of 1941-1960 and 1961-1990 (see Table 2).

Assuming that buildings in different periods were built and registered equally, we get that during 1950-1970, when it is probable that PCBs in buildings were used most widely (Heinzow et al., 2007), 171,282 buildings (without auxiliary buildings) were registered, of which 8,600 were apartment houses and 51,950 various public buildings. Investigations in other countries suggest that one apartment house can contain up to $50-60 \mathrm{~kg}$ of PCBs, and a big building up to $100 \mathrm{~kg}$ of PCBs (Benthe et al., 1992). Calculations based on these assumptions would result in 3,027-6,055 t of PCBs in buildings in Lithuania.
Nevertheless, such an estimate, which does not even include private houses, seems to be an overestimate of PCBs prevalence: as it was demonstrated in the calculations above, it is likely that the overall import of PCBs to Lithuania could be some $1,900 \mathrm{t}$, of which some 400 t could be in open systems, i.e. mostly in buildings. That results in no more than $6.6 \mathrm{~kg}$ of PCBs in one building (apartment house or public building).

Residential and public buildings built in the period of 1950-1970 have been chosen for sampling. The samples were taken from construction materials, which potentially could contain PCBs, i.e. from sealants, paint and concrete (Table 3).

The resulting spectrogram is shown in Fig. 2.

Analysis showed that test samples do contain some kind of aromatic compounds, which might potentially be namely PCB compounds. Although this was a screen-

\begin{tabular}{|c|c|c|c|}
\hline \multirow{7}{*}{$\begin{array}{r}\text { Number of } \\
\text { registered buildings } \\
\text { constructed in the } \\
\text { period of } 1941-1990 \\
\text { (Centre of Registers } \\
2015)\end{array}$} & Building uses & 1941-1960, number & 1961-1990, number \\
\hline & 1 & 2 & 3 \\
\hline & Residential buildings & 91,181 & 221,225 \\
\hline & of them houses having three and more flats (apartment houses) & 3,748 & 20,179 \\
\hline & $\begin{array}{l}\text { Non-residential buildings, not including auxiliary buildings } \\
\text { among them administrative buildings, hotels, trade, } \\
\text { services, catering and recreational buildings, culture, } \\
\text { science and sports buildings, manufacturing, industrial } \\
\text { buildings }\end{array}$ & 10,743 & 139,734 \\
\hline & Buildings, not including auxiliary buildings & 101,924 & 360,959 \\
\hline & All buildings & 363,647 & $1,402,968$ \\
\hline
\end{tabular}

Table 3

Coverage of construction materials that potentially can contain PCBs with the samples taken for investigation

\begin{tabular}{l|c|c}
\hline \multicolumn{1}{c|}{$\begin{array}{c}\text { Construction material } \\
\text { potentially containing PCBs }\end{array}$} & Samples taken & Notes \\
\hline 1 & 2 & 3 \\
\hline Sealants & $+(1$ sample $)$ & Concrete block seams \\
\hline Gypsum & - & Paint from walls \\
\hline Tiles & - & \\
\hline Paint & $+(5$ samples $)$ & Building construction \\
\hline Glue & - & \\
\hline Concrete & $+(4$ samples $)$ & \\
\hline
\end{tabular}




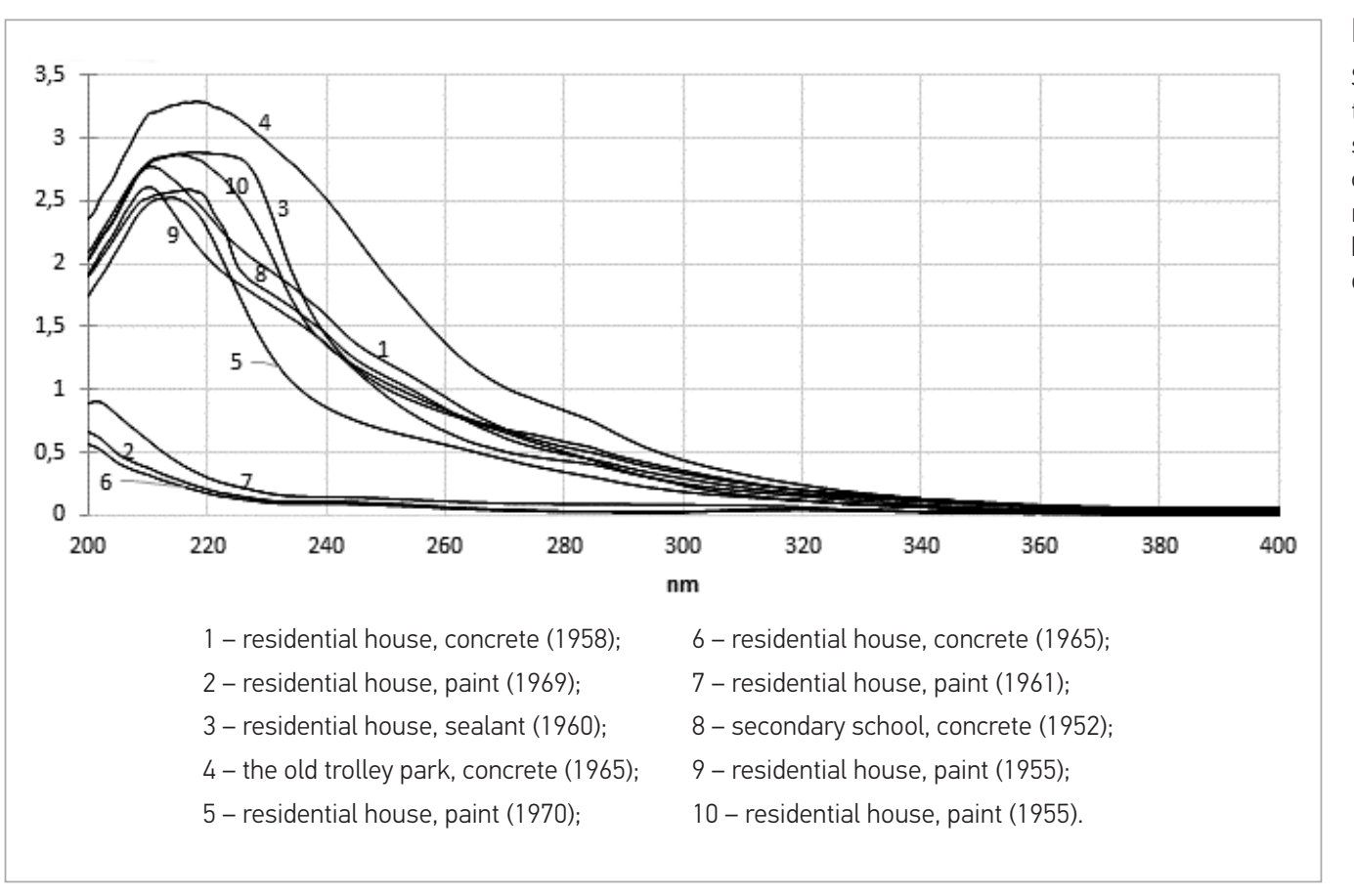

Fig. 2

Spectrogram of the investigated samples of construction materials from buildings built during 1950-1970 ing analysis only, it demonstrates that contamination of buildings with PCBs in Lithuania might be an issue as well as in other countries which have carried out more detailed investigations. Currently, PCB-containing construction and demolition waste is collected in Lithuania by waste management company UAB Toksika and disposed of in a hazardous waste landfill in Šiauliai.

\section{Conclusions}

According to theoretical calculations, about 1,900 t of PCBs could be brought into Lithuania and used in closed, partially closed and open systems. It is most probable that PCBs under the trade name Sovol, produced in Russia, constituted the majority of PCBs in open systems, i.e. some $400 \mathrm{t}$. Assuming that the peak consumption of PCBs for construction materials coincides with that in other countries, there are 8,600 apartment houses and 51,950 various public buildings with a big probability to contain PCBs. One such building could contain up to $6.6 \mathrm{~kg}$ of PCBs. UV/ VIS spectrometric screening analysis confirmed the probability of contamination for samples taken from buildings built in the period of 1950-1970.

\section{References}

AMAP (Arctic Monitoring and Assessment Programme) (2000). PCB in the Russian Federation: Inventory and proposals for priority remedial actions. Report 2000: 3.

Andersson M., Ottesen R.T., Volden T. (2004). Building materials as a source of PCB pollution in Bergen, Norway. Science of the total environment 325: 139 - 144. http://dx.doi. org/10.1016/j.scitotenv.2003.11.014
Benthe Ch., Heinzow B., H Jessen H., et al. (1992). Polychlorinated biphenyls. Indoor air contamination due to Thiokol - rubber sealants in an office building. Chemosphere 25 (7-10): 1481 - 1486. http://dx.doi.org/10.1016/0045-6535(92)90173-0

Breivik K., Sweetman A., Pacyna J., Jones K. (2002). Towards a global historical emission inventory for selected PCB congeners - a mass balance approach 1. Global production and 
consumption. The Science of the Total Environment 3: 181198. http://dx.doi.org/10.1016/S0048-9697(01)01075-0

Breivik K., Sweetman A., Pacyna J., Jones K. (2007). Towards a global historical emission inventory for selected PCB congeners - a mass balance approach 3. An update. The Science of the Total Environment 377: 296-307. http://dx.doi. org/10.1016/j.scitotenv.2007.02.026

Brown K.W., Minegishi T., Cummiskey C.C., Fragala M.A., Hartman R., Maclntosh D. (2016). PCB remediation in schools: a review. Environmental Science and Pollution Research 23(3): 1986-1997. http://dx.doi.org/10.1007/s1 1356-015-4689-y

Buika A., Getautis V., Martynaitis V. et al. (2007). Organiniu junginiu spektroskopija. Kaunas: Technologija. (Spectroscopy of organic compounds)

Butera S., Christensen T. H., Astrup T.F. (2014). Composition and leaching of construction and demolition waste: inorganic elements and organic compounds. Journal of Hazardous Materials 276: 302-311. http://dx.doi.org/10.1016/j. jhazmat.2014.05.033

Centre of registers (2015). Lietuvos respublikos nekilnojamojo turto registre iregistruotu statiniu apskaitos duomenys 2015 m. sausio 1 d. Vilnius, 2015. (Register of Property)

Heinzow B., Mohr S., Ostendorp G., et al. (2007). PCB and dioxin - like PCB in indoor air of public buildings contaminated with different PCB sources - deriving toxicity equivalent concentrations from standard PCB congeners. Chemosphere 67: 1746 - 1753. http://dx.doi.org/10.1016/j.chemosphere.2006.05.120

Herrick, R. F., McClean, M. D., Meeker, J. D., Baxter, L. K., \& Weymouth, G. A. (2004). An unrecognized source of PCB contamination in schools and other buildings. Environmental Health Perspectives 112: 1051-1053 http://dx.doi. org/10.1289/ehp.6912

Herrick R. F. (2010). PCBs in school - persistent chemicals, persistent problems. New Solutions 20 (1): 115 - 126. http:// dx.doi.org/10.2190/NS.20.1.h

Kaunelienè V., Prasauskas T., Krugly E., et al (2016). Indoor air quality in low energy residential buildings in Lithuania. Building and Environment 108: 63-72. http://dx.doi.org/10.1016/j. buildenv.2016.08.018
Kohler M., Tremp J., Zennegg M., et al. (2005). Joint sealants: an overlooked diffuse source of polychlorinated biphenyls in buildings. Environmental Science and Technology 39 (7): 1967 - 1973. http://dx.doi.org/10.1021/es048632z

Lehmann G.M., Christensen K., Maddaloni M. et al. (2015). Evaluating Health Risks from Inhaled Polychlorinated Biphenyls: Research Needs for Addressing Uncertainty. Environmental Health Perspectives 123 (2): 109 - 113.

Lithuanian MoE (2010). Dèl patvariuju organinių teršalu (POT) tvarkymo 2010-2015 metu programos patvirtinimo. LR aplinkos ministro isakymas Nr. D1-1034. (Order on approval of persistent organic pollutants management programme for 2010-2015).

Maclntosh D., Minegishi T., Fragala M., Allen J., Coghlan K. et al. (2012). Mitigation of building - related polychlorinated biphenyls in indoor air of a school. Environmental Health 11 (24): 1 - 10. http://dx.doi.org/10.1186/1476-069x-11-24

Priha E., Hellman S., Sorvari J. (2005). PCB contamination from polysulphide sealants in residential areas - exposure and risk assessment. Chemosphere 59 (4): 537 - 543. http:// dx.doi.org/10.1016/j.chemosphere.2005.01.010

Seldén A.I., Lundholm C., Johansson N. et al. (2008). Polychlorinated biphenyls (PCB), thyroid hormones and cytokines in construction workers removing old elastic sealants. International Archives of Occupational Environmental Health 82: 99 - 106. http://dx.doi.org/10.1007/s00420-008-0313-5

UNEP (United Nations Environment Programme) (1999). Guidelines for the Identification of PCBs and Materials Containing PCBs.

UNEP (United Nations Environment Programme) (2001). The Stockholm convention on persistent organic pollutants (POPs). Available at: http://chm.pops.int/default.aspx (accessed 01 August 2016).

Wagner U.K. (2010) Inventories of PCBs: An expert's point of view. PEN Magazine 01: 9-11. Available at: http://chm.pops. int/Implementation/PCBs/PCBEliminationNetwork/Activities/PENmagazine/tabid/738/Default.aspx (accessed 01 August 2016).

WHO/IPCS (World Health Organisation /International Program on Chemical Safety) (1993). Polychlorinated biphenyls and terphenyls. Environmental Health Criteria, Geneva. 


\section{About authors}

\section{Dr. JOLITA KRUOPIENE்}

Professor, Institute of Environmental Engineering, Kaunas University of Technology.

Main research area(s): chemicals control and management, integrated waste management, environmental impact assessment, water resources management.

Address: Gedimino 50, LT-44239 Kaunas, Lithuania, tel.: +370 37 300767, e-mail: jolita.kruopiene@ktu.lt

\section{EGLE் JURKĖNE்}

M.SC. student, Institute of Environmental Engineering, Kaunas University of Technology.

Main research area(s): chemicals control and management, chemical and biological analysis.

Address: Gedimino 50, LT-44239 Kaunas, Lithuania, tel.: +370 37 300767, e-mail: e.jurkene@gmail.com

\section{Dr. GINTARAS BUIKA}

Professor, Faculty of Chemical Technology, Kaunas University of Technology.

Main research area(s): polymers chemistry, organic synthesis, materials science.

Address: Radvilènų 19A, Kaunas, Lithuania, tel.: +370 37 300189, e-mail: gintaras.buika@ktu.lt

\section{Dr. SIGITA ŽIDONIENÉ}

Chemicals expert, Baltic Environmental Forum, Lithuania.

Main research area(s): chemicals control and management at enterprise level, environmental impact assessment, life cycle assessment, public awareness rising.

Address: Užupio 9/2- 17, LT-01202 Vilnius, Lithuania, tel.: +370 5 2159288, e-mail: sigita.zidoniene@bef.lt

\section{Dr. JOLANTA DVARIONIENĖ}

Professor, Institute of Environmental Engineering, Kaunas University of Technology.

Main research area(s): sustainable consumption and production, life cycle assessment (LCA), water management, chemicals management and control, energy efficiency, environmental impact assessment.

Address: Gedimino 50, LT-44239 Kaunas, Lithuania, tel.: +370 37 300767, e-mail: jolanta.dvarioniene@ktu.lt 


\section{Polichlorinti bifenilai atvirose sistemose Lietuvoje}

\section{Jolita Kruopienė, Eglè Jurkènè, Jolanta Dvarionienè}

Kauno technologijos universitetas, Aplinkos inžinerijos institutas

Gedimino 50, LT-44239 Kaunas, Lietuva

\section{Gintaras Buika}

Kauno technologijos universitetas, Cheminès technologijos fakultetas

Radvilènu 19A, Kaunas, Lithuania

\section{Sigita Židonienè}

Lietuvos Baltijos aplinkos forumas, Užupio 9/2- 17, LT-01202 Vilnius, Lietuva

Polichlorinti bifenilai (PCB) - toksiškos, patvarios ir biologiškai besikaupiančios medžiagos, dèl savo pavojinguju savybiu jtrauktos i Stokholmo konvenciją. Ši konvencija, issigaliojusi 2004 m., draudžia (su vos keliomis laikinomis išimtimis) i ją itrauktu pavojingu organinių cheminių medžiagu gamybą ir naudojimą bei reikalauja saugaus medžiagu pašalinimo iš ju ankstesniuju naudojimų. PCB plačiausiai buvo naudojami apie $1970 \mathrm{~m}$. kondensatoriuose ir transformatoriuose. Ilgainiui kaupési įrodymai apie PCB daromą neigiamą poveiki aplinkai ir žmoniu sveikatai, vis plačiau įsigaliojo su PCB susiję draudimai. Stokholmo konvencijos šalims narems rengiant pirmuosius nacionalinio igyvendinimo planus (NIP), daugiausia orientuotasi i PCB naudojimą uždarose sistemose, t.y. kondensatoriuose ir transformatoriuose. Lietuvoje, kaip ir daugelyje kitu šalių, kondensatorių ir transformatorių alyvų su PCB nukenksminimas didžiaja dalimi jau yra atliktas. Tačiau mokslininkai kai kuriose šalyse, kaip Švedijoje, Šveicarijoje, Vokietijoje, atkreipe dèmesi, kad PCB galejo būti gana plačiai naudoti ir atvirose sistemose, t.y. pastatuose - sandarikliuose, dažuose (pavyzdžiui, betono), plieno antikorozinèse dangose, elektros kabeliu apsauginiuose apvalkaluose ir kt. Manoma, kad apie 21\% PCB sunaudota būtent pastatuose. Šveicarijoje, Vokietijoje PCB aptiktas patalpu, pavyzdžiui mokyklų, ore.

Šiame straipsnyje pateikiami teoriniai PCB paplitimo atvirose sistemose, kurios pagrinde yra pastatai, vertinimai. Nustatyta, kad i Lietuvą galejo patekti apie 1900 tonų PCB, kurie naudoti tiek uždarose, tiek pusiau uždarose, tiek atvirose sistemose. Atvirose sistemose, tikètina, sunaudota apie 400 tonų PCB prekiniu Sovol'io pavadinimu, gamintų Rusijoje. Šalyje yra apie 8600 daugiabučių namų ir 51950 jvairių visuomeninès paskirties pastatu, kuriuose yra didele tikimybe aptikti PCB. Viename tokiame pastate gali būti iki 6,6 kg PCB. Atlikti apžvalginiai UV/VIS spektrometriniai tyrimai, paemus mėginius iš 10 pastatų, statytu 1950-1970 m. laikotarpiu, parodè, kad yra tikimybè, jog jie užteršti PCB. 